\title{
The Influence of Angiography Table Shields and Height on Patient and Angiographer Irradiation During Interventional Radiology Procedures
}

\author{
B. Janne d'Othée $\cdot$ Pei-Jan Paul Lin
}

Published online: 1023

(C) Springer Science+Business Media, LLC 2007

Erratum to: Cardiovasc Intervent Radiol

DOI 10.1007/s00270-006-0063-2

Re: Cardiovasc Intervent Radiol (2007) 30:448-454 - In the online version of this article, the first author's name was cited incorrectly. It appears correctly below:

B. Janne d'Othée

The online version of the original article can be found under doi: 10.1007/s00270-007-0063-2

B. Janne d'Othée · P.-J. P. Lin

Department of Radiology, Beth Israel Deaconess Medical

Center-Harvard Medical School, Boston, Massachusetts, USA

B. Janne d'Othée ( $\square)$

Section of Interventional Radiology, Department of Radiology, Beth Israel Deaconess Medical Center-Harvard Medical School, 330 Brookline Avenue-W/CC 385, Boston, MA 02215-5400,

USA

e-mail: bjanne@caregroup.harvard.edu 